\title{
Cross-sectional study of the dispensation of synthetic anorectic drugs in community pharmacies in the city of Cruz Alta - State of Rio Grande do Sul
}

\author{
Marcieli Maria Navarini', Viviane Cecilia Kessler Nunes Deuschle ${ }^{2, *}$, \\ Regis Augusto Norbert Deuschle ${ }^{3}$
}

\author{
${ }^{1}$ Faculty of Pharmacy, University of Cruz Alta, Rio Grande do Sul, Brazil,, ${ }^{2,3}$ Postgraduate Program in Pharmaceutical \\ Sciences, Federal University of Santa Maria, Brazil
}

\begin{abstract}
Obesity is defined as the excess adipose tissue in the body. Drugs responsible for inhibiting the appetite are called anorectics or appetite suppressants. Sibutramine, fenproporex and amfepramone belongs to this class, and are capable of causing physical or psychological dependence. The aim of this study was to evaluate the frequency of prescriptions for appetite suppressants in community pharmacies at Cruz Alta, State of Rio Grande do Sul, Brazil. The sales of fenproporex, amfepramone and sibutramine in the months of September, October and November 2010 and April, May and June 2011 were compared. It was observed that the most commonly dispensed anorectic in the three community pharmacies analyzed was sibutramine. In the months of September, October and November 2010, consumption was higher, with sibutramine achieving $40.3 \%$ of overall sales, amfepramone $21 \%$ and, finally, fenproporex, $7.9 \%$. The consumption of appetite suppressants was more prevalent in females, who represented $82 \%$ of total. The results suggested the existence of high consumption of anorectics, possibly related to the current concern with aesthetic standards, which emphasizes the importance of strict control over the marketing of these substances.
\end{abstract}

Uniterms: Drugs/prescriptions. Drugs/marketing control. Obesity/treatment. Anorectics. Amphetamine.

Obesidade define-se como excesso de tecido adiposo no organismo. Os fármacos responsáveis por inibir o apetite são denominados anorexígenos ou supressores de apetite. Sibutramina, femproporex e anfepramona, pertencentes a essa classe, são capazes de provocar dependência física ou psíquica. O objetivo deste estudo foi avaliar a prevalência da prescrição de anorexígenos em farmácias comerciais de Cruz Alta - RS. Foi comparada a venda dos fármacos femproporex, anfepramona e sibutramina, nos meses de setembro, outubro e novembro de 2010 e abril, maio e junho de 2011. Observou-se que o anorexígeno mais prescrito nas três farmácias analisadas foi a sibutramina. Nos meses de setembro, outubro e novembro de 2010 , o consumo foi maior, quando a sibutramina alcançou um percentual de $40,3 \%$, a anfepramona $21 \%$ e, por fim, o femproporex, $7,9 \%$. O consumo de inibidores de apetite foi mais prevalente no sexo feminino, o qual representou $82 \%$ do total. Os resultados sugeriram a existência de elevado consumo de anorexígenos, possivelmente relacionada à preocupação com padrões estéticos atuais, o que ressalta a importância de um controle rigoroso sobre a comercialização destas substâncias.

Unitermos: Fármacos/prescrição. Fármacos/controle comercial. Obesidade/tratamento. Anorexígenos. Anfetamina.

*Correspondence: V. C. K. N. Deuschle. UFSM campus, Building 26, room 1132,97105-900, Santa Maria - RS, Brasil.E-mail: vivianenunes1@yahoo.com.br 


\section{INTRODUCTION}

Obesity is a public health problem that affects millions of people and has a complex treatment that involves modifying dietary habits through reeducation. It also covers caloric restriction, physical activity, and behavioral changes (Almeida, Polese, Ribeiro, 2000; Mancini, 2002).

For a long time, the treatment of obesity was an option subject to much criticism due to the irrational use of available drugs and the abuse of drugs sold by compounding pharmacies. The process is undergoing a revaluation, showing that obese individuals must accomplish appropriate steps to weight loss, under medical supervision (Gray et al., 2012).

Self-medication can be defined as a situation when a person has the initiative of consuming a medicine without professional guidance. This behavior can be observed among obese people, and also among individuals with aesthetic motivations who do not have this morbidity (Paulo, Zanini, 1998).

A large portion of appetite suppressants (also known as anorectics) is based on amphetamines, which were synthesized to combat obesity and depression, in early 1920 s. Later, their use became popular among young people to reduce sleepiness and gain a better body shape. However, their major therapeutic indication remains the treatment of obesity, becoming part of most formulations for appetite reduction (Murer, 2007). They stimulate the central nervous system and suppress appetite, and can also cause amphetamine syndrome, which is characterized by euphoria, decreased fatigue, and increased intellectual capacity (Silva, 1998).

Fenproporex and amfepramone are amphetamine derivatives widely used as anorectics, for assisting in the treatment of obesity. Even being known as substances with high potential for abuse and dependence, they are among the most prescribed drugs in Brazil. The indiscriminate use of appetite suppressants may pose a risk to their users, since these drugs can have serious side effects. Thus, this study aims to estimate the frequency of use of appetite suppressants such as fenproporex, amfepramone and sibutramine.

\section{MATERIAL AND METHODS}

Data were obtained from the database of three randomly selected commercial community pharmacies from the city of Cruz Alta, in the northwestern region of Rio Grande do Sul State, Brazil. Each establishment was located in the city downtown. In this cross- sectional observational study, we analyzed the frequency of dispensations of three anorectics: fenproporex, sibutramine, and amfepramone. Data were obtained from the National System of Controlled Product Management (SNGPC), a database that allows to control the consumption of controlled drugs in each pharmacy. We analyzed the frequency of dispensations from the months of September, October and November 2010 and April, May and June 2011.

Data tabulation was performed using Microsoft ${ }^{\circledR}$ Excel ${ }^{\circledR} 2010$ software. The frequency of the prescription of the selected drugs was determined by gender and according to the season: September, October and November (spring time) and April, May and June (autumn time).

\section{RESULTS AND DISCUSSION}

This study analyzed a total of 315 prescriptions. It was found that the most sold anorectic drug in the three commercial pharmacies was sibutramine, with 170 prescriptions (representing 54\% of total sales), followed by amfepramone, with 104 (33\%) and fenproporex, with $41(13 \%)$. Literature regarding the level of dispensation of these drugs among the general population is scarce. Differently from what we found, a study by Nadja et al. (2010), observed that the most consumed of these drugs was fenproporex, followed by amfepramone and sibutramine. Another study, reported that amphetamine substances are highly used among nursing students, and that most of them began to use these substances when they started academic life. The use of anorectics was justified by the stress generated by the new routine and by the amount of activities performed at the university (Mardegan et al., 2007). Noto et al. (2002) found that compounding pharmacies are a major source of dispensation of anorectic drugs, the most prescribed of which were amfepramone and fenproporex. Bejola et al. (2009) evaluated medical prescriptions and showed that, in $50 \%$ of cases, appetite suppressants are prescribed as monotherapy, and that the most prescribed drugs were fenproporex $(26 \%)$, followed by amfepramone $(12 \%)$ and sibutramine $(11 \%)$. The data found in our study are not in agreement with the available literature, which allows to infer that our results may have been influenced by specific factors related to prescription, e.g., clinician preferences or adoption of specific therapeutic regimens. The fact of literature pointing out that community pharmacies can also be sources of acquisition of these drugs for non-therapeutic purposes is enough to suggest more studies on the topic.

Figure 1 shows the analysis of 315 prescription notifications, revealing that there is a difference in 
consumption of anorectic drugs in different seasons. The consumption of the three drugs was much more higher in the months of September, October and November 2010, with sibutramine achieving a total of 127 prescriptions (40.3\%), followed by amfepramone, with $66(21 \%)$ and fenproporex, with 25 (7.9\%). In the months of April, May and June 2011, there were $43(13.6 \%)$ prescriptions of sibutramine, $38(12.1 \%)$ of amfepramone, and $16(5.1 \%)$ of fenproporex. These results are similar to those found in the literature. An investigation by Feltrin et al. (2009) comparing the consumption of anorectics between the months of September 2006 and February 2007 found that the largest amounts of drugs were dispensed in November 2006 (17.67\%), followed by October 2006 (17.67\%), December 2006 (17.32\%), January 2007 (15.71\%), September 2006 (14.80\%) and, finally, February 2007 (13.81\%), which had the lowest rate of sales. These results suggest that the demand for anorectic drugs increases with proximity to summer in Brazil, possibly due to a greater concern with appearance and increased exposure of the body at this time of year (Silva, 2002). Generally, these drugs are used by individuals who are concerned only to reducing weight gained during the winter season and who do not have the profile required for this type of treatment (Feltrin et al., 2009).

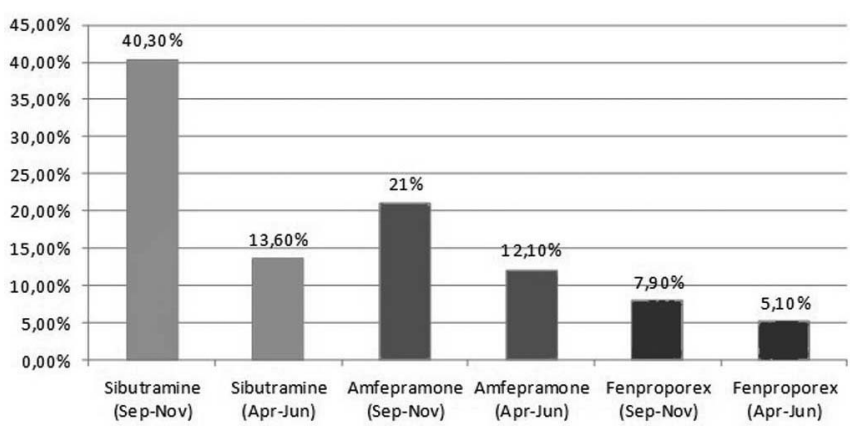

FIGURE 1 - Percentage of each drug dispensed by months September to November 2010 and April to June 2011.

Data shown in figure 2 demonstrate that the percentages of consumption remained virtually identical among men and women in both periods, being higher among women, who were responsible for ordering $122(81.8 \%)$ prescriptions in the months of September, October and November 2010 (approaching summer) and 67 prescriptions (81.7\%) in the months of April, May and June 2011 (next to winter), when exposure of the body is minimum. In male patients, there was less consumption, which accounted for $27(18.2 \%)$ prescriptions in the months of September, October and November 2010 and 15 (18.3\%) prescriptions in the months of April, May and June 2011.

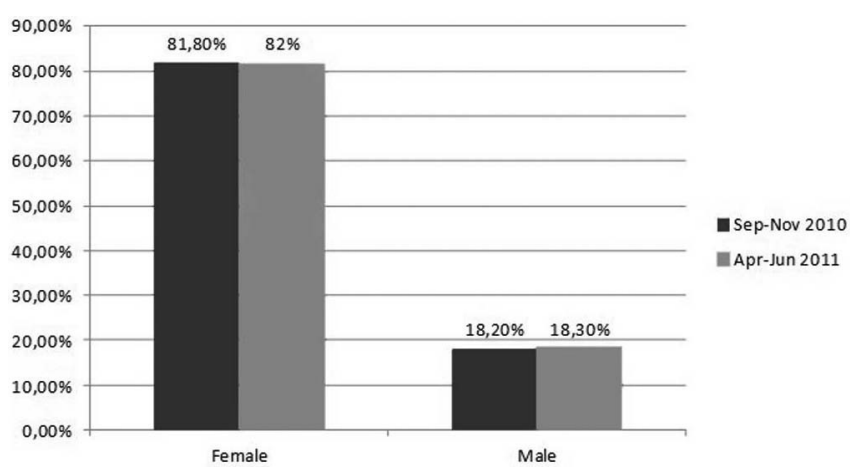

FIGURE 2 - Consumption of anorectics: gender/season relation.

It can be observed that the use of appetite suppressants was more prevalent in females. These values are in agreement with those found in the study by Feltrin et al. (2009), who showed that $93.35 \%$ of users of anorectic drugs were females and only $6.65 \%$ were males. Another study consistent with the data in Figure 3 was performed by Bejola et al. (2009), who found that females accounted for $80 \%$ of total consumption of anorectic drugs, while men accounted for $20 \%$. These results suggest that the use of this type of substance between women is probably related to aesthetical motivations (Lopes et al., 1997). This probable concern with aesthetics is reinforced considering that consumption was higher in warmer months among both sexes, despite being markedly higher in females than in males.

According to Figure 3, we observed that the dispensation of sibutramine was higher in pharmacy $\mathrm{B}$, representing 87 (51.2\%) dispensations, followed by pharmacy C, with 44 (25.8\%), and pharmacy A, with 39 (23\%). The largest amount of amfepramone was dispensed in pharmacy B, with $56(53.8 \%)$ dispensations, followed by pharmacy C, with 36 (34.6\%), and pharmacy A, with $12(11.6 \%)$. Fenproporex showed a higher level of dispensation in pharmacy A, where they accounted for 17

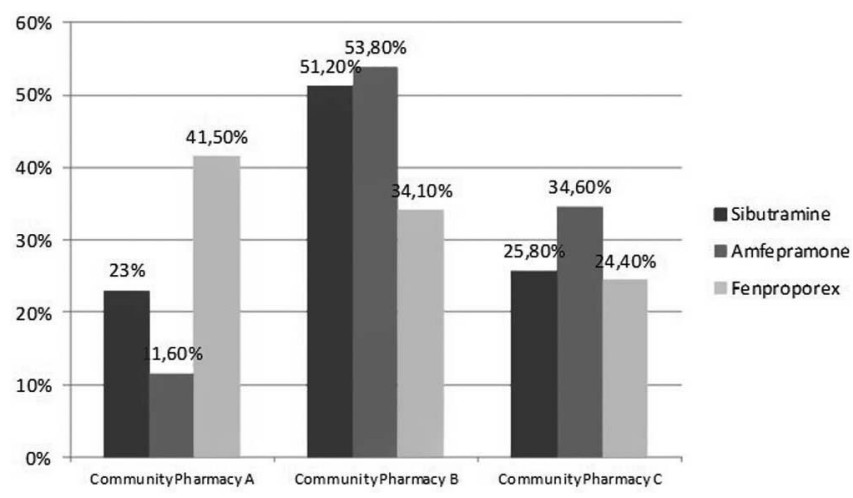

FIGURE 3 - Anorectics dispensation frequency in community pharmacies A, B e C. 
(11.6\%) dispensations, followed by pharmacy B, with 14 (34.1\%), and pharmacy C, with 10 (24.4\%). According to a study conducted in community pharmacies at Belo Horizonte, Brazil, the pharmacy that stood first in sales of psychotropic anorectics accounted for $39.8 \%$ of all notifications. Some reasons for higher frequencies of dispensations could be the quality offered in price policy and services, as well as marketing strategies (Carneiro, Guerra Jr, Acurcio, 2008).

\section{CONCLUSION}

The findings in this study suggest that consumption of anorectics in the population studied is possibly linked to aesthetic motivations, whose current standards primarily affect women. Consumption was greater in the warmer months approaching summer, i.e., September, October and November, when the most prescribed drug was sibutramine. This is the time when people have greater physical exposure and are more concerned about staying within an aesthetically ideal low weight. Considering aesthetics as a possible motivation for these findings, drug treatment is not considered the best option for a faster weight loss. Also, considering the implication of these drugs with possible damage to the health as a result of misuse, further studies are suggested to evaluate the reasons that motivated the consumption of anorectics among the population studied, a topic that was not evaluated in this work.

\section{REFERENCES}

ALMEIDA, A.; RIBEIRO, M.; POLESE, L. Determination of amfepramone hydrochloride, fenproporex, and diazepam in so-called "natural" capsules used in the treatment of obesity. J. Liq. Chrom. Rel. Technol., v. 23, n.7, p.1109-1118, 2000.

BEJOLA, A.; OLIVEIRA, M.M.S.; VIRTUOSO, S. Avaliação de anorexígenos e suas associações prescritas em uma farmácia com manipulação do município de Toledo-PR. Visão Acadêmica, v.10, n.2, p.116-122, 2009.

CARNEIRO, M.F.G.; GUERRA JÚNIOR, A.A.; ACURCIO, F.A. Prescrição, dispensação e regulação do consumo de psicotrópicos anorexígenos em Belo Horizonte, Minas Gerais, Brasil. Rio de Janeiro. Cad. Saúde Pública, v.24 n.8, p.1763-1772, 2008.
FELTRIN, A.C.; ZORDAN, G.; WAGNER, F.; SCHMITT, C.; BOLIGON, A.A.; DELAMOLLE, N.; ATHAYDE, M.L.; VAUCHER, L.C. Medicamentos anorexígenos panorama da dispensação em farmácias comerciais de Santa Maria (RS). Rev. Saúde, v.35, n.1, p.46-51, 2009.

GRAY, L.J.; COOPER, N.; DUNKLEY, A.; WARREN, F.C.; ARA, R.; ABRAMS, K.; DAVIES, M.J.; KHUNTI, K.; SUTTON, A. A systematic review and mixed treatment comparison of pharmacological interventions for the treatment of obesity. Obes. Rev., v.13, n.6, p.48-498, 2012.

LOPES, H.; PAIXÃO, H.H.; MONTEIRO, S.L.; PEDROSA, R.C. Formulações para emagrecimento: uso e abusos. Rev. Ciênc. Farm., v.2, p.125-137, 1997.

MANCINI, M.C. Obesidade cresce e aumenta o risco de doenças no Brasil. Vida saudável. 35.ed. São Paulo, 2002.

MARDEGAN, P.S.; SOUZA, R.S.; BUAIZ, V.; SIQUEIRA, M.M. Uso de substâncias psicoativas entre estudantes de enfermagem.J. Bras. Psiquiatr., v.56, n.4, p.260-266, 2007.

MURER, E. Drogas, anfetaminas e remédios para emagrecer. In: VILARTA, R.(Ed.). Alimentação saudável, atividade fisica e qualidade de vida. Campinas: Ipes Editorial, 2007.

NADJA, C.L.B.; LIMA, A.F.D.; SIMÕES, W.M.B. Uso de substâncias psicoativas entre acadêmicos de enfermagem da universidade católica de Minas Gerais. Rev. Eletr. Saúde Mental Álcool Drog., v.6, n.1, p.1-13, 2010.

NOTO, A.R.; CARLINI, E.; MASTROIANNI, P.C.; ALVES, V.; GALDUROZ, J.C.; KUROIWA, W.; CSIZMAR, J.; COSTA, A.; FARIA, M.; HIDALGO, S.R.; ASSIS, D.; NAPPO, A. Análise da prescrição e dispensação de medicamentos psicotrópicos em dois municípios do Estado de São Paulo. Rev. Bras. Psiquiatr., v.24, n.2, p.68-73, 2002.

PAULO, L.G.; ZANINI, A.C. Automedicação no Brasil. São Paulo. Rev. Assoc. Med. Bras., v.34, p.69-75, 1988.

SILVA, P. Farmacologia. 5.ed. Rio de Janeiro: Guanabara Koogan, 1998.

SILVA, P. Farmacologia. 6.ed. Rio de Janeiro: Guanabara Koogan, 2002.

Received for publication on $24^{\text {th }}$ January 2013 Accepted for publication on $04^{\text {th }}$ October 2013 